\title{
In Search of Deeper Learning
}





\section{In Search of Deeper Learning}

THE QUEST TO REMAKE THE AMERICAN HIGH SCHOOL

Jal Mehta ANd Sarah Fine

II Harvard University Press

Cambridge, Massachusetts

London, England 2019 
Copyright (C) 2019 by the President and Fellows of Harvard College All rights reserved

Printed in the United States of America

First printing

Cover image: Martin Shields/Getty Images

Cover design: Graciela Galup

9780674239968 (EPUB)

9780674239975 (MOBI)

978067423995 I (PDF)

Library of Congress Cataloging-in-Publication Data is available from loc.gov.

ISBN 978-o-674-98839-2 (alk. paper) 